\title{
Biotechnology based on cell cultures of higher plants
}

\author{
Amira Nourani ${ }^{1, *}$, Elena Popova ${ }^{2}$ and Maria Titova ${ }^{2}$ \\ ${ }^{1}$ Peoples' Friendship University of Russia (RUDN University), 117198, 6 Miklukho-Maklaya Street, \\ Moscow, Russian Federation \\ ${ }^{2}$ K.A. Timiryazev Institute of Plant Physiology of Russian Academy of Sciences, 127276, 35 \\ Botanicheskaya st., Moscow, Russia
}

\begin{abstract}
This paper reviews the role of plant cell culture as a biotechnological tool in preserving the botanical diversity of higher plants while meeting the growing demand of the commercial market for large volumes of plant raw material. The prospects of plant cell-based technology are discussed in the framework of creating an economy of sustainable development in the short and long term.
\end{abstract}

\section{Introduction}

Conservation of biodiversity of higher plants in ex situ collections, such as botanical gardens, seed and plant banks in vitro, is one of the most promising and actively developing strategies for the conservation of plant genetic resources worldwide [1].

Modern biotechnological tools enable the formulation and development of new solutions for the protection of botanical plant biodiversity. One of such solutions is the in vitro method of cultivation of plant cells and organs, which is based on the idea of totipotency - the possibility of preserving the "memory" of the functional potential of the whole organism in individual cells. In vitro cultures of plant cells and organs can serve on the one hand, as a renewable source of biologically active secondary metabolites [2] and, on the other hand, can become the basis for developing new varieties with valuable traits.

In addition, establishment of in vitro collections of cultured plant cells represents a promising alternative method of providing renewable plant sources for Hi-Tech industrial production based on cell cultures [1].

\section{Cell culture and conservation of plant biodiversity}

Plants produce about 100,000 kinds of known metabolites, and many new compounds from plants continue to be discovered every year [3]. The demand for higher plants for food production and for the needs of the pharmaceutical industry has increased in recent decades.

\footnotetext{
* Corresponding author: 1032194279@pfur.ru
} 
Pharmaceutical companies rely heavily on plant materials from rapidly depleting natural sources. Plants collected in the wild account for up to $80-90 \%$ of plant raw materials for commercial production [2], so the need for alternative renewable sources of plant biomass has increased significantly in recent decades, especially for rare and endemic plant species. The traditional cultivation of medicinal plants on plantations in time-consuming and requires the use of pesticides, which often discredits the quality of the produced plant biomass.

For this reason, the search for alternative and self-sustaining biotechnological methods for the production of plant raw materials of high quality is actively developing all over the world. Application of such methods would reduce the collection of wild plants and thus contribute to the preservation of their biodiversity.

Plant cell culture allows the production of plant biomass of controlled quality to meet the needs of the commercial market, with the ability to scale up the production process and increase the yield of the desired product without the use of toxic insecticides and herbicides [4]. It should be noted that cell-based biotechnologies are dependent heavily on the development and use of cell strains with the ability to accumulate biologically active compounds in greater quantities compared to wild plants [5]. The presence of active metabolites, including various isomeric forms, that are unusual or seldomly presented in wild plants is another asset of cell culture that recently attracted researchers' interest [1].

The commonly discussed advantages of cell cultures compared to wild and plantation cultivated plants is the possibility to product biomass with guaranteed quality and desired characteristics, regardless of season, climatic changes and environmental conditions. In addition, cell-based technologies are ecologically friendly and fit well in the most recent trends of sustainable production systems and responsible consumptions [1].

\section{Cell culture in the economic market}

From the very start of the research on plant cell cultures, their commercial use has attracted attention [6] whether for pharmacological, cosmetics, food production or for the industrial use of natural dyes, and the demand for cell-derived products in the market is growing.

\subsection{Cell cultures for pharmaceuticals}

The richest sources of medicinal substances are medicinal plants. In recent decades, suspension plant cell cultures have been successfully used for the production of valuable secondary metabolites with high biological activity [7].

The development of plant cell culture methods has significantly diversified the production of secondary metabolites of commercial interest, such as alkaloids, phenolic components, isoprenoids, and indole alkaloids. The latter are one of the most diverse groups of secondary metabolites used in medicine as an anticancer agent (camptothecin, vincristine, and vinblastine, as well as the antiarrhythmic alkaloid aymalin) [2].

By 1989, the sales of plant derived products on the North American Market increased on an average by three billion US dollars annually, moreover, in Europe 2000, in China 10,000 species are used as medicinal plants [2].

For instance, culturing of plant cells has been considered as a promising alternative for the efficient production of ginseng biomass and its active ingredients, which pharmacological functions include antiplatelet, hypocholesterolemic, antitumor, immunomodulatory functions, and help improving the central nervous system [8].

According to Transparency Market Research estimates, by 2025 the global market for anticancer drugs will reach 155.6 billion US dollars [9]. For example, paclitaxel which is produced from the Taxus sp. in Canada, USA, Germany and South Korea [1]. 


\subsection{Cell culture for the dye industry}

Cell cultures can be used to obtain natural dyes [6]. It should be noted that the market for natural dyes is one of the fastest growing markets for the food and cosmetics industry with an estimated volume of the global anthocyanin market of \$ 291.7 million in 2014 and a forecast of $\$ 387.4$ million for 2021 [6,9]. For example, cell cultures are a promising commercial source of shikonine [5]. It has been shown that the amount of shikonine produced by the cell culture of Lithospermum erythrorhizon was 20 times greater than that existing in the intact plant $[2,10]$.

\subsection{Cell cultures for the cosmetic industry}

The global cosmetics market is increasing every year, and the demand for raw materials for the cosmetics industry is high.

The emerging trend of manufacturing cosmetics and food products in a natural and sustainable manner has brought a new wave in plant cell culture technology over the past 10 years. More than 50 products based on extracts from plant cell cultures have made their way into the cosmetics industry during this time, whereby many are produced with plant cell suspension cultures [11].

Plants such as Rhodiola rosea, Aloe barbadensis, Ajuga reptans, Echinacea spp., and Calendula spp. are most popular in cosmetology [11]. Recently, cell cultures of crop and model plants such as Nicotiana sylvestris, Malus domestica, Rubus idaeus, Vitis vinifera, Daucus carota, Oryza sativa, Coffea bengalensis, Syringa vulgaris, Rhododendron hirsutum, Camellia sinensis have been also utilized [1]. It was shown that extracts of cell biomass have anti-inflammatory, antioxidant, and UV-protective activity; and activate the processes of skin regeneration [12].

\subsection{Cell culture for the production of food supplements}

The food supplements and additives industry represent a great opportunity in the global economic market. In addition, individual food ingredients are the basis of major global industries [13].

Such an approach has been implemented in a Zurich University of Applied Sciences (ZHAW) study which investigated the potential of callus and suspension cell lines of Theobroma cacao for the cocoa ingredient in chocolate production [11]. Another study on plant cell cultures from cloudberry, lingonberry and stoneberry validated the great potential of plant cell cultures for food purposes [14]. In Russia, cell culture biomass of a medicinal plant Polyscias filicifolia is used in a series of food supplements including "Vitagmal", which was demonstrated to have anti-teratogenic and immunomodulating actions.

The annual world market for plant-derived vanilla flavor is estimated at more than US \$ 250 million, while the total annual worldwide herbal extracts market was recently estimated at US \$ 17.5 billion $[14,15]$.

Table 1. Examples of historical and present biotechnologies based on plant cell cultures

\begin{tabular}{|c|c|c|c|}
\hline Company (country) & Species & Product & Reference \\
\hline $\begin{array}{c}\text { Bristol-Myers Squibb } \\
\text { USA/Global }\end{array}$ & Taxus sp. & Paclitaxel & {$[16]$} \\
\hline $\begin{array}{c}\text { Phyton Catalytic formed in } 1990 \text { in } \\
\text { Ithaca, NY, USA }\end{array}$ & Taxus sp. & Paclitaxel & {$[17]$} \\
\hline
\end{tabular}




\begin{tabular}{|c|c|c|c|}
\hline Company (country) & Species & Product & Reference \\
\hline $\begin{array}{l}\text { Samyang Biopharmaceuticals } \\
\text { Corp., Seoul, Korea }\end{array}$ & Taxus sp. & Paclitaxel & [18] \\
\hline \multirow{2}{*}{ ESCA genetics (USA), CA, USA } & Taxus sp. & Paclitaxel & {$[19,20,21]$} \\
\hline & Vanilla planifolia & Vanilline & [22] \\
\hline \multirow{3}{*}{$\begin{array}{l}\text { Mitsui Petrochemical Industries } \\
\text { (Japan) }\end{array}$} & $\begin{array}{l}\text { Lithospermum } \\
\text { erythrorhizon var. } \\
\text { erythrorhizon Sieb. } \\
\text { et Zucco }\end{array}$ & $\begin{array}{l}\text { A mixture } \\
\text { of shikonin } \\
\text { derivatives }\end{array}$ & $\begin{array}{c}{[23,24} \\
25,26,27] \\
{[28,29,30]}\end{array}$ \\
\hline & Coptis japonica & Berberine & $\begin{array}{l}{[22,31,} \\
32,33]\end{array}$ \\
\hline & $\begin{array}{l}\text { Catharanthus } \\
\text { roseus }\end{array}$ & $\begin{array}{l}\text { Formation of } \\
\text { vinblastine from } \\
\text { vincristine } \\
\text { Catharanthine } \\
\text { Arbtin }\end{array}$ & {$[34,35]$} \\
\hline \multirow{2}{*}{$\begin{array}{l}\text { DIVERSA Gesellschaft fur Bio-und } \\
\text { Verfahrenstechnik mbH } \\
\text { (Germany) }\end{array}$} & $\begin{array}{l}\text { Rauwolfia } \\
\text { serpentina }\end{array}$ & $\begin{array}{l}\text { Indole alkaloids } \\
\text { Raucaffricine } \\
\text { Ajmaline }\end{array}$ & {$[36,36,37]$} \\
\hline & $\begin{array}{l}\text { Echinacea } \\
\text { purpurea, } \\
\text { Echinacea } \\
\text { augustifolia }\end{array}$ & $\begin{array}{l}\text { Immunostimulat- } \\
\text { ing } \\
\text { polysaccharides }\end{array}$ & [38] \\
\hline PCC Technology Inc. Japan (500 1) & Aralia cordata & Anthocyanins & [39] \\
\hline $\begin{array}{l}\text { Sumitomo Chemical Co., Ltd. } \\
\text { (Japan) }\end{array}$ & Duboisia & Scopolamine & {$[35,40]$} \\
\hline Nippon Oil (Japan) & Podophyllum & Podophyllotoxin & [35] \\
\hline $\begin{array}{c}\text { A. Nattennann \& Cie. GmbH, } \\
\text { Biotechnology/Plant Cell Culture, } \\
\text { Postfach 350120, } 5000 \text { Koln 30, } \\
\text { FRG (Germany) }\end{array}$ & Coleus blumei & Rosmarinic acid & [41] \\
\hline Nitto Denko (Japan) & Panax ginseng & Cell biomass & [42] \\
\hline Kibun (Japan) & $\begin{array}{l}\text { Carthamus } \\
\text { tinctorius }\end{array}$ & Cartamine & {$[34,44,45]$} \\
\hline Nippon Shinyaku (Japan) & Beta vulgaris & Betacyanins & {$[38,46]$} \\
\hline Nippon Paint (Japan) & Euphorbia milli & Anthocyanins & [38] \\
\hline PCC Technology Inc. Japan (500 1) & Aralia cordata & Anthocyanins & [40] \\
\hline $\begin{array}{l}\text { Boehringer Mannheim Co. } \\
\text { (Germany) }\end{array}$ & Digitalis lanata & $\begin{array}{l}\text { Biotransformation } \\
\text { products of } \\
\text { cardiac glycosides }\end{array}$ & [47] \\
\hline
\end{tabular}




\begin{tabular}{|c|c|c|c|}
\hline Company (country) & Species & Product & Reference \\
\hline $\begin{array}{c}\text { Japan Tobacco Inc. Tokyo, Japan } \\
\text { Later }\end{array}$ & Nicotiana tabacum & $\begin{array}{c}\text { Nicotine, tobacco } \\
\text { biomass }\end{array}$ & {$[48-55]$} \\
$\begin{array}{c}\text { The Japan Tobacco and Salt Public } \\
\text { Corporation }\end{array}$ & & & \\
\hline
\end{tabular}

\section{Problems and prospects}

In vitro plant cell cultures are a biotechnological strategy widely used for the production of biomass and metabolites with medicinal value for pharmaceuticals, cosmetology and food industries. Plant cell culture is a renewable, environmentally friendly and safe source of target substances that can be adapted for large-scale production.

However, the industrial application of plant cell cultures for the production of secondary metabolites is still not widespread, mainly due to the high costs of production process, the duration and high cost of certification of the resulting products, particularly for the pharmacological application [6].

In order to improve biomass production, several strategies have been used to increase the product yields at the production stage which include changes in medium composition, addition of inducers or precursors, elicitation [56], stress exposure, genetic engineering approaches or mutagenesis [57] which affect the qualitative and quantitative composition of the compounds synthesized [1].

Recent developments in this area allow to assume that, in the foreseeable future, industrial cultivation of plant cells combined with the development of superproducer cell lines will make a solid base for the biotechnological production of biomass and secondary metabolites to meet the growing needs of the commercial market. In turn, the transition to environmentally friendly, renewable raw materials in the form of cell cultures will help

The research was carried out with the financial support of the Ministry of Science and Higher Education of the Russian Federation under the Megagrant project (agreement No. 075-15-2019-1882).

\section{References}

1. E. V. Popova, A. V. Nosov, M. V. Titova, Kochkin D. V., A. A. Fomenkov, I. E. Kulichenko and A. M. Nosov, Russ. J. Plant Physiol., 68, 3, (2021) (to be published)

2. A. M. Nosov, Bioch. and Microbiol., 48(7), 609-624 (2012)

3. J.J. Zhong, J. Bios. Bioeng., 94(6), 591-599 (2002)

4. V. M. Loyola-Vargas and N. Ochoa-Alejo, Methods in molecular biology (Clifton, N.J.), 1815, 3-13 (2018).

5. I. Smetanska, Biochem Engin/Biotec., 111, 187-228 (2008)

6. I. Appelhagen, A.K. Wulff-Vester, M. Wendell, A.K. Hvoslef-Eide, J. Russell, A. Oertel, S. Martens, H.P. Mock, C. Martin. and A. Matros, Metab. Eng., 48, 218-232 (2018).

7. Sagar S. Arya, James E. Rookesb, David M. Cahillb, Sangram K. Lenkaa. Biotech. Adv. 45, 1076352. (2020). 
8. T. T. Nguyen, N. M. Hosakatte and P. Kee-Yoeup, Production of Biomass and Bioactive Compounds Using Bioreactor Technology, 121-142 (Springer Science+Business Media Dordrecht, 2014)

9. Trancparency Market Research in-depth Analysis, Accurate Results. https://www.transparencymarketresearch.com/

10. R. S. Ramachandra, G.A. Ravishankarb, Biotec. Adv., 20, 101-153 (2002).

11. R. Eibl, P. Meier, I. Stutz, D. Schildberger, T. Hühn, and D. Eibl, Appl. Microbiol. Biotechnol., 102, 8661 (2018)

12. A. Barbulova, F. Apone, and G. Colucci, Cosmetics, 1, 94 (2014)

13. K.M. Davies and S.C. Deroles, Current Opinion in Biotechn., 26:133-140 (2014)

14. E. Nordlund, M. Lille, P. Silventoinen, H. Nygren, T. Seppänen-Laakso, A. Mikkelson, A.M. Aura, R.L. Heiniö, L. Nohynek, R. Puupponen-Pimiä and H. Rischer, Food Res. Inter., 107, 297-305 (2018)

15. J. Steingroewer, T. Bley, V. Georgiev, I. Ivanov, F. Lenk, A. Marchev, A. Pavlov Eng. Life Sci., 13, 26-38 (2013)

16. H. Tabata, Current Drug Targets, 7(4), 453-461 (2006).

17. https://phytonbiotech.com.

18. H.K. Choi, J.S. Son, G.H. Na, S.S. Hong, Y.S. Park, \& J.Y. Song, Jour. Pl. Biotec., 29(1), 59-62 (2002)

19. M.E. Wall, M.C. Wani, Alkaloids: chemical \& biological perspectives, 1-21. (Els. Sci. Ltd., Pergamon, 1995)

20. D. Davidson, P.J. Hylands, W.R. Sharp, R.W. Stahlhut, Medicinal resources of the tropical forest. Biodiversity and its importance to human health, 19-40 (Columb. Univ. Press, NY, USA, 1996)

21. J. Goodman, V. Walsh, The story of taxol: nature and politics in the pursuit of an anticancer drug (Camb. Univ. Press, Cambridge, UK, 2001)

22. A. Stafford, Trends in Food Science and Technology, 2, 116-122 (1991)

23. Mitsui Petrochem Ind Ltd (1982a) Jpn Patent J 57039-778 8.

24. Mitsui Petrochem Ind Ltd (1982b) Jpn Patent J 57039-779 9.

25. Y. Fujita, Y. Hara, T. Ogino, C. Suga, Plant Cell Rep 1, 59-60 (1981)

26. Y. Fujita, Y. Hara, C. Suga, T. Morimoto, Pl. Cell Rep 1, 61-63 (1981)

27. Y. Fujita, Y. Maeda, C. Suga, T. Morimoto Pl. Cell Rep 2, 192-193 (1983)

28. M. Tabata, Y. Fujita Biotechnology in Plant Science, 207-218 (Orlando, 1985)

29. M.E. Curtin, Bio/Technology, 1, 649-657 (1983)

30. K. Yazaki, Plant Biotechnol (Tokyo), 34(3), 131-142 (2017)

31. A. Sasson, Biotechnology: economic and social aspects. Issues for developing countries, 81-109 (Camb. Univ. Press., Cambridge, USA. 1992)

32. A. Sabater-Jara, L. Tudela, A. Lo' pez-Pe' rez, Phytochem Rev., 9, 343-356 (2010)

33. Y. Fujita, M. Tabata, Plant tissue and cellculture, 169-185 (Alan R. Liss, New York, 1987)

34. M. Misawa, Plant tissue culture: an alternative for production of useful metabolite (Food and Agriculture Organization of the United Nations Rome Italy, 1994) 
35. P. Sharma, S. Sharma, S. Yadav, A. Srivastava, I. Purohit and N. Shrivastava, Production of Biomass and Bioactive Compounds Using Bioreactor Technology, 47-60 (Spr. Sci.+Bus. Media Dordrecht, 2014)

36. K. Westphal, Progress in Plant Cellular and Molecular Biology, 601-608 (Kluwer Academic, 1990)

37. E. Rittershaus, J. Ulrich, A. Weiss, K. Westphal, BioEng., 5, 28-34 (1989)

38. S.A. Wilson, S.C. Roberts, Plant Biotechnol. J., 10(3), 249-68 (2012)

39. T.J. Fu, G. Singh, W.R. Curtis, Plant cell and tissue culture for the production of food ingredients, 1-6 (Spr. Sci.Bus. Media, NY, USA, 1999)

40. Y. Kobayashi, M. Akita, K. Sakamoto et al., Appl. Microbiol. Biotechnol., 40, 215-218 (1993)

41. B. Ulbrich, W. Wiesner, H. Arens, Primary and Secondary Metabolism of Plant Cell Cultures, 293-303 (Spr.-Verlag Ber., Heidelberg, 1985)

42. K. Hibino, K. Ushiyama, Commercial Production of Ginseng by Plant Tissue Culture Technology. (Spr., Boston, MA, 1999)

43. N. J. Smart \& M. W. Fowler, J. Experimental Botany, 35(4), 531-537 (1984)

44. Kubin Co. (1987) Japan patent 87-126924.

45. K. Kusaka, S. Wakayama, In: Plant cell culture in Japan, 127-137 (CMC Co., Tokyo, Japan, 1991)

46. T. Akita, Y. Hina \& T. Nishi, Nippon shokuhin kagaku kogaku kaishi, 49(4), 238-244 (2002)

47. A.W. Alfermann, H. Spieler, E. Reinhard, In: Primary and Secondary Metabolism of Plant Cell Cultures. Proceedings in Life Sci., 316-322 (Spr., Berlin, Heidelberg, 1985)

48. S. Azechi, T. Hashimoto, T.Yuyama, S. Nagatuska, M. Nakashizuka, T. Nishiyama, A.Murata, Hakkokogaku, 61, 117-128 (1983)

49. A. Kato, A. Asakura, K. Tsuji, F. Ikeda, M. Iijima, J. Ferment. Technol., 58, 373-382 (1980)

50. A. Kato, Y. Hashimoto, Y. Soh, J. Ferment. Technol. 54, 754-757 (1976)

51. A. Kato, Y. Hukazawa, Y. Shimizu, Y. So, S. Nagai, J. Ferment. Technol., 55, 207-212 (1977)

52. A. Kato, S. Kawazoe, M. Iijima, Y. Shimizu, J. Fer. Technol., 54, 82-87 (1976)

53. A. Kato, S. Kawazoe, Y. Soh, J. Fer. Technol., 56, 224-228 (1978)

54. A. Kato, Y. Shimizu, S. Nagai, J. Fer. Technol., 53, 744-751 (1975)

55. K. Kato, Y. Shiozawa, A. Yamada, K. Nishida, M. Noguchi, Agric. Biol. Chem., 36, 899-902 (1972)

56. N. M. Hosakatte and P. Kee-Yoeup, Food Ingredients from Plant Cell, Tissue and Organ Cultures: Bio-safety and Efficacy Evaluations (Spr. Sci.+Bus. Media Dordrecht., 2014)

57. H.N. Murthy, V.S. Dandin, J.-J. Zhong, and K.-Y. Paek, in: Production of Biomass and Bioactive Compounds Using Bioreactor Technology, 471-508 (Spr.-Verlag, Dordrecht, 2014) 